\title{
口腔扁平上皮癌および良性疾患における核小体形成体 （Ag-NORs）の発現に関する検討
}

\author{
早津良和・松村耕治・过 龍 雄 \\ 井上敬・森本宏志*・篠崎文彦
}

\section{Study on the nucleolar organizer regions associated protein (Ag-NORs) in oral squamous cell carcinoma and benign lesions}

\author{
Yoshikazu Hayatsu - Kouji Matsumura - Tatsuo Tsuji \\ Takashi Inoue • Hiroshi Morimoto* • Fumihiko Shinozaki
}

\begin{abstract}
By using a silver staining technique, nucleolar organizer regions associated protein (Ag-NORs) have been studied in paraffin sections of oral squamous cell carcinomas, benign lesions, such as leukoplakia and papilloma, and normal oral mucosa. The mean numbers of $\operatorname{Ag-NORs~were:~squamous~cell~carcinoma~}(n=19), 6.18 \pm 1.84$; papilloma $(n=9), 2.70 \pm 0.50$; leukoplakia $(n=10), 2.92 \pm 0.69$; normal oral mucosa $(n=4), 2.48 \pm 0.13$. There was a significant difference in the mean number of Ag-NORs between squamous cell carcinoma and the other two groups $(\mathbf{P}>0.05)$. The number of Ag-NORs seemed to have relations to the cellular atypism of squamous cell carcinoma and the grade of epithelial dysplasia of leukoplakia. These findings suggest that quantification of Ag-NORs may be used for differential diagnosis of malignant and benign oral tumors, and estimation of proliferative activity of oral preneoplastic and neoplastic lesions.
\end{abstract}

Key words: nucleolar organizer regions (核小体形成体), oral squamous cell carcinoma (口腔 扁平上: 皮癌), cellular atypism（細胞異型度）

緒

言

核小体形成体 (Nucleolar organizer regions; NORs) は，蛋白合成を行うリボゾームの合成に関与している核 小体の形成に重要な働きを担っている。このため NORs

山口大学医学部崊科口腔外科学講座

（主任：篠崎文彦教授）

* 山口大学医学部病理学第 2 講座

(主任：高橋 学教授)

Department of Oral and Maxillofacial Surgery, School of Medicine, Yamaguchi University (Chief: Prof. Fumihiko Shinozaki)

* 2nd Department of Pathology, School of Medicine, Yamaguchi University (Chief: Prof. Manabu Takahashi)

受付日：平成 4 年 2 月 20 日
は細胞の蛋白合成能力ひいては増殖力と密接な関係があ ると考えられている。この NORs の主体はリボゾーム RNA を転写する DNA のループにあり ${ }^{1)}$, ヒトの正常 染色体では D群 (No. 13〜15) とG群 (No. 21，22) の短腕部にあることが分かっている2).

最近, 銀コロイド染色法の開発 ${ }^{3)}$ により, 核小体形成 体の関連蛋白 (Argyrophiric nucleolar regions associated protein；Ag-NORs）を容易かつ迅速に染色することが 可能になり, 種々の臓器に扣いて腫瘍の良性, 悪性の鑑 別や悪性度の指標に用いられている

今回,われわれは口腔扁平上皮癌扣よび良性疾患に打け るAg-NORsの発現に関して検討を行ったので報告する.

\section{対 象と方 法}

\section{1. 対象症例}

検索対象は, 山口大学医学部附属病院歯科口腔外科を 
表 $1 \mathrm{Ag}-\mathrm{NOR}$ s 染色法
1）ホルマリン固定, パラフィン包埋
2) $3 \mu \mathrm{m}$ 切片
3) 脱パラ
4）後固定（エタノール，酢酸）
5) 水 洗
6）染色（室温30分）
7) 水 洗
8）脱水，透徹, 封人

染色液 A : $2 \%$ ゼラチン $1 \%$ ギ酸

B : $50 \%$ 硝酸銀液

使用直前に A, B 学 1：2に混合占る。

表 2 正常口腔粘膜扣よび各種疾患の平均 Ag-NORs 数

\begin{tabular}{|c|c|c|c|}
\hline 組織型 & 症例数 & Ag-NORs 数 & S.D. \\
\hline 正漟口腔粘膜 & 4 & $\begin{array}{c}2.48 \\
(2.36 \sim 2.69)\end{array}$ & 0.13 \\
\hline 白板症 & 10 & $\begin{array}{c}2.92 \\
(1.65 \sim 4.30)\end{array}$ & 0.69 \\
\hline 乳頭腫 & 9 & $\begin{array}{c}2.70 \\
(2.11 \sim 3.61)\end{array}$ & $0.50 \ldots *$ \\
\hline 侖平上皮癌 & 19 & $\begin{array}{c}6.18 \\
(4.08 \sim 11.92)\end{array}$ & 1.84 \\
\hline
\end{tabular}

受診し，検索しえた頭頸部扁平上支癌 19 例，白板症 10 例，乳頭腫 9 例，ならびに正常口腔粘膜 4 例である。扁 平上皮癌症例は男性13例, 女性 6 例で, 年齢は $44 \sim 74$ 歳 であった。部位は口底 7 例, 舌 5 例, 歯肉, 上頭洞各 3 例，口蓋 1 例であった。白板症症例は男性 3 例, 女性 7 例で, 年秢は29〜75歳であり, 舌, 歯肉各 4 例, 煩粘膜 2 例であった. 乳頭腫症例は, 男性 2 例, 女性 7 例で, 年齡は $10 \sim 72$ 歳であり, 舌 5 例, 歯肉 2 例, 口蓋, 下唇 各 1 例であった。

\section{2. 研究方法}

$\mathrm{Ag}-\mathrm{NORs}$ の染色は, ホルマリン固定パラフィン包埋 後, $3 \mu \mathrm{m}$ の切片を作製し, 脱パラ後, Ploton $5^{12)}$ の方 法に準じて行った（表 1 ）.

Ag-NORs の個数は, 400 倍顕微鏡下に細胞 100 個の $\mathrm{Ag}-\mathrm{NORs}$ 染色陽性顆粒数を数兄, 細胞 1 個当りの平均 Ag-NORs 数を算定した.

\section{結果}

各疾患の平均 $\mathrm{Ag}-\mathrm{NORs}$ 数は白板症では 2.92 0.69 , 乳頭腫では2.70土0.50, 扁平上皮癌では $6.18 \pm 1.18$ であ

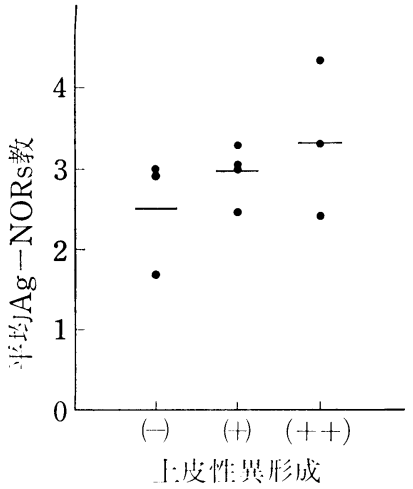

図 1 白板症に扣訬る異形成别の Ag-NORs 数

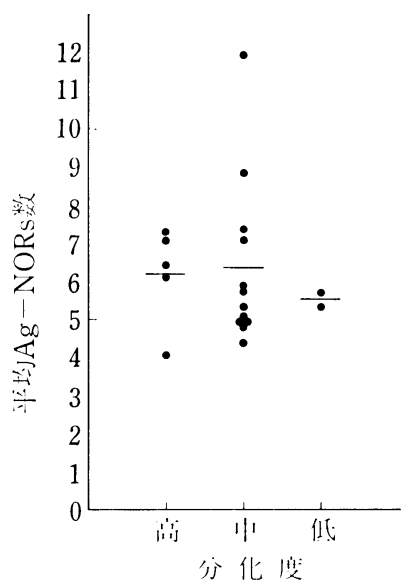

図 2 居平上:波癌分化度别の Ag-NORs 数

り，正常口腔粘膜では $2.48 \pm 0.13$ であった（写真 1 ）. Ag-NORs 数に関して正常口腔粘膜, 白板症, 乳頭腫と 扁平上皮癌との間には有意差（ $\mathrm{t}$ 検定， $\mathrm{P}<0.05 ）$ を認 めたが，正常口腔粘膜と白板症，乳頭腫との間には有意 差はなかった（表 2)。

白板症の!:皮界形成を程度により 3 段階（一○十+） に分け，それぞれの Ag-NORs 数について比較した。

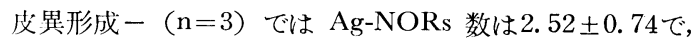
上皮異形成 $+(\mathrm{n}=4)$ では2.92 0.34 , 上皮異形成十+

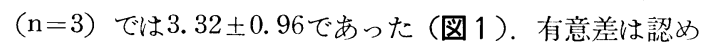
なかったが, 上皮異形成が増すに従い Ag-NORs 数も増 加する傾向にあった。

扁平上皮癌症例に拈いて，分化度別に Ag-NORs 数を 及ると, 高分化型 $6.18 \pm 1.26(\mathrm{n}=5)$, 中分化型 $6.30 \pm$ $2.20(\mathrm{n}=12)$ ，低分化型 $5.28 \pm 0.28(\mathrm{n}=2)$ であった (図 2). 症例数に偏りがあるが, 分化度とAg-NORs 数 


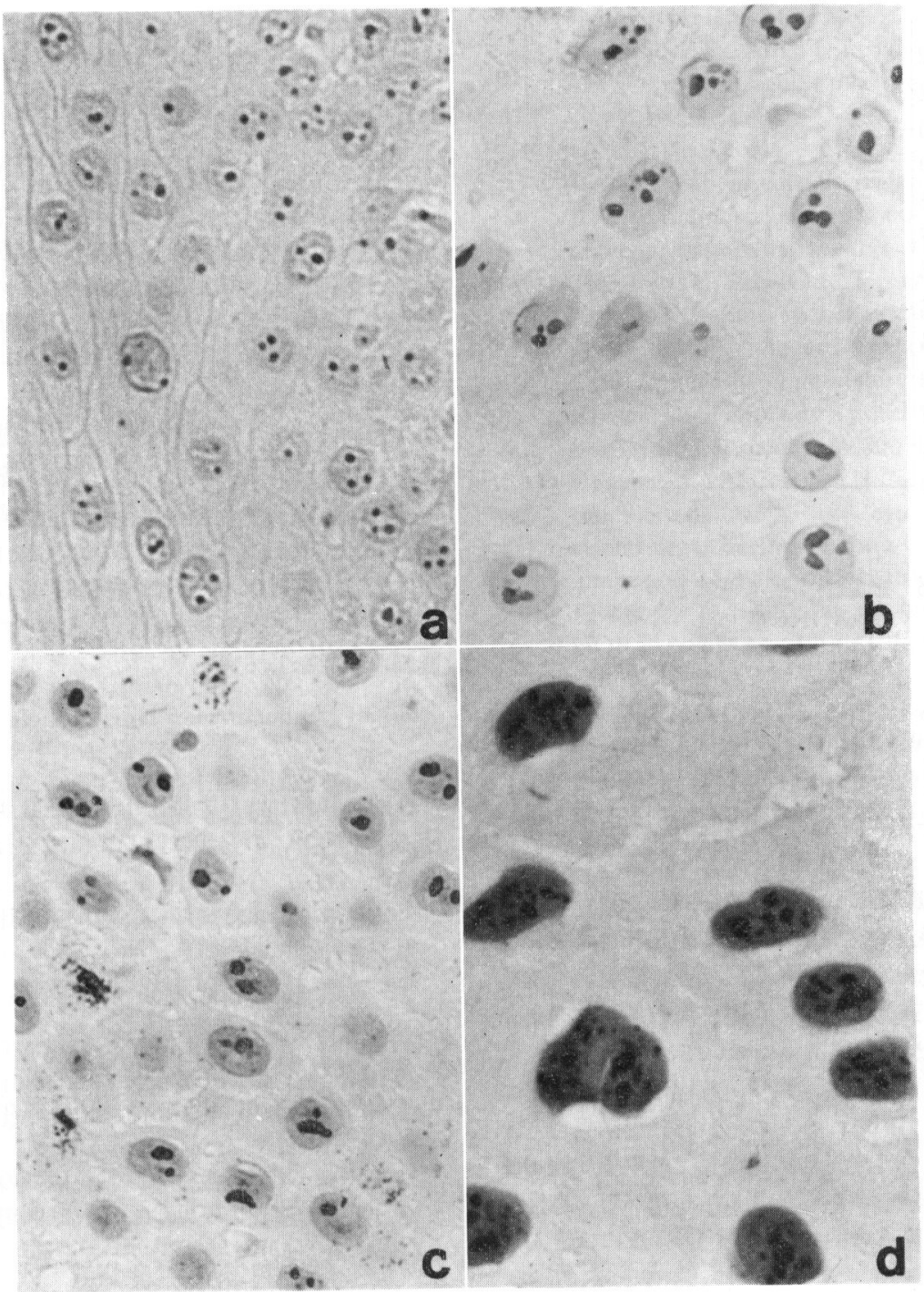

写真 $1 \mathrm{Ag}-\mathrm{NORs}$ 染色の顥微鏡像
a：正常口腔粘膜
b : 白板症（舌, 異形成）
c : 乳頭腫 (舌)
$\mathrm{d}$ ：扁平上皮癌（舌, 高分化, 低異型度）

との間には関連性は認められなかった。

扁平上皮癌の異型度と $\mathrm{Ag}-\mathrm{NORs}$ 数との関連では, 低 異型度 $5.54 \pm 0.88(\mathrm{n}=6)$, 中異型度 $5.68 \pm 1.49(\mathrm{n}=$ $5)$, 高異型度 $6.89 \pm 2.44(\mathrm{n}=8)$ であり, 異型度が増 すに従い Ag-NORs 数は増加する傾向がみられた（図 3).

\section{考} 察

一般に静止期の細胞に打いて，核小体に近接して酸性
リン酸化蛋白が認められる ${ }^{13)}$. これらの蛋白は好銀, 非 ヒストン酸性蛋白で, 銀染色により染色され, 核小体形 成体関連蛋白 (Ag-NORs) とよばれている ${ }^{14)}$. この染 色はNバンド染色法とよばれ, 染色体検査に用いられて いたが，1980年に Howell and Black ${ }^{3)}$ がゼラチンを用 いた銀コロイド染色法を報告して以来，簡便で迅速に行 光, 再現性のある染色法としてパラフィン切片にも応用 されるようになった。

Ag-NORs に関して, 生物学的には十分に解明されて いないが， RNA polymerase $\mathrm{I}^{12)}$ や C23 蛋白などに関 


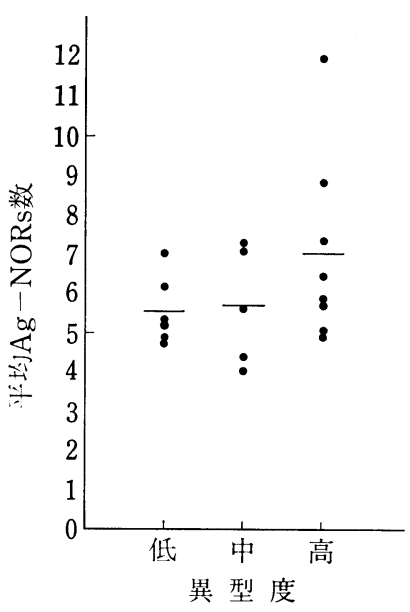

図 3 扁平上皮癌異型度別の Ag-NORs 数

連があると考えられている(13)。 また，Ag-NORs 数は $\mathrm{Ki}-67$ 陽性細胞数 ${ }^{15)}$ ， BrdU 標識率 ${ }^{16)}$, DNA フローサ イトメトリーによる $\mathrm{S}$ 期細胞数 ${ }^{17)}$ とよく相関する。これ らのことから Ag-NORs 数は細胞増殖能を示す指標と 考えられ, これまで造血器 ${ }^{4)}$, 肺 ${ }^{5,8)}$, 乳腺6,18), 消化 器 ${ }^{7,11)}$, 膀胱 ${ }^{19)}$, 皮膚 ${ }^{9)}$ な゙のさまざまな腫陽で $\mathrm{Ag}-$ NORs 数の測定が良性, 悪性の判定に有用であると報告 されている. 最近では, Ag-NORs 染色の細胞診への応 用も報告 $8,18,20)$ されている. 口腔外科領域では当科の Matsumura ら ${ }^{10)}$ が喠液腺腫瘍において，悪性腫瘍では $\mathrm{Ag}-\mathrm{NORs}$ 数が有意に多く, 良性, 悪性の鑑別に有用で あることを報告している. 今回のわれわれの結果でも， 乳頭腫, 白板症の良性疾患群に比較して扁平上皮癌では $\mathrm{Ag}-\mathrm{NORs}$ 数が有意に多かった。 しかしながら，良性疾 患群と正常口腔粘膜との間には Ag-NORs 数にほとんど 差が認められなかった。

白板症症例に括いては異形成が，扁平上皮癌症例に拉 いては異型度が増すに従い, 統計学的に有意差はなかっ たが Ag-NORs 数が増加する傾向が認められた。したが って, Ag-NORs 数は上皮異形成の程度を表す 1 つの指 標となりらると考えられた. 白板症では上皮の異形成的 变化を認めたものは, 認めなかったものに比べ約 8 倍の

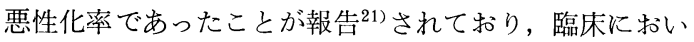
て異形成を判定することは重要である。またこれまで, 悪性リンパ腫 ${ }^{4)}$, 胃癌 ${ }^{11)}$, 膀胱の移行上皮癌 ${ }^{19}$ におい て Ag-NORs 数と腫瘍の 異型度には相関があることが 報告されており, われわれの扁平上皮癌においても同様 の結果が得られた. 異型度は扁平上皮癌に执いて, 予後 に大きく関与する因子の 1 つ考えられている ${ }^{22)}$. した がって, Ag-NORs 数の測定は悪性度の評価の一助とな ることが示唆される。一方, 腫瘍の分化度と Ag-NORs
数との間には相関は認められなかった. Ag-NORs 数の 増加は細胞増殖能の高い細胞核内では核小体の解離が 生じ, Ag-NORs が分散する結果であると説明されてい $ろ^{23)}$.

これまで細胞增殖能の評価には, BrdU, Ki-67, DNA フローサイトメトリーなどが用いられていたが，いずれ も新鮮組織が必要であり, 検体の取り扱いが繁雑であっ たり，熟練した手技が要求された。このようなことから 臨床に打ける応用には制約があった。 これに対して AgNORs は, ホルマリンもしくはェタノール固定パラフィ ン包埋された標本で染色が可能であり, 染色操作も簡便 で，短時間で行える利点をもち，広く臨床応用が可能で あると考えられる。最近, Ag-NORs 数, 面積などをよ り客観的に解析するため, 画像解析装置を利用した自動 解析も行われるようになってきた ${ }^{18)}$ 。また， Ag-NORs

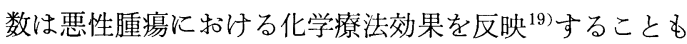
指摘されて扣り，今後われわれもさらに症例数を増やし 詳細な検討をしていく予定である。

\section{結語}

今回われわれは口腔扁平上皮癌, 乳頭腫, 白板症にお ける Ag-NORs の発現に関して検討を行い，以下の結果 を得た。

1）扁平上皮癌は乳頭腫, 白板症に比べて Ag-NORs 数が有意に多かった.

2) 乳頭腫, 白板症と正常口腔粘膜との間には $\mathrm{Ag}$ NORs 数に有意な差はなかった。

3）白板症に拉いては上皮異形成が，また扁平上皮癌 では異型度が増すに従いAg-NORs 数が増加する傾向が 認められた。

以上, Ag-NORs 数は口腔粘膜病変の増殖能の評価や 良性, 覀性の鑑別の一助として臨床応用ができるのでは ないかと考えられた。

本論文の要旨は，筝45回日本口腔科学:会総令（1991年: 5 月17日，京都）に扣いて発表した。

\section{引用文 献}

1) Alberts, B., Bray, D., ct al.: Molecular biology of the cell. Garland, New York, 1983, p 424-426.

2) Goodpasture, C. and Bloom, S.E.: Visualisation of necleolar organizer regions in mammalian chromosomes using silver staining. Chromosoma 53: 37-50 1975.

3) Howell, W.M. and Black, D.A.: Controlled silver-staining of nucleolus organizer regions with a protective colloidal developer: a 1-step method. Experientia 36: 1014-1015 1980. 
4) Crocker, J. and Nar, P.: Nucleolar organizer regions in lymphomas. J Pathol 151: 111-118 1987.

5) Crocker, J., Ayres, J., et al.: Nucleolar organizer regions in small cell carcinoma of the bronchus. Thorax 42: 972-975 1987.

6) Giri, D.D., Lawry, N.J., et al.: Silver-binding nucleolar organizer regions (Ag-NORs) in benign and malignant breast lesions: Correlations with Ploidy and DNA flow cytometry. J Pathol 157: 307-313 1989.

7) Derenzini, M., Romagnoli, T., et al.: Interphasic nucleolar organizer region distribution as a diagnostic parameter to differentiate benign from malignant epithelial tumors of human intestine. Virch Arch B Cell Pathol 54: 334-340 1988.

8）小倉滋明, 阿部庄作, 他 : Nucleolar organizer regions からみた気管支!: 皮異型過形成細胞と 腺癌細胞の相違。肺湢 29: 771-776 1989.

9) Egan, M.J. and Crocker, J.: Nucleolar organizer regions in cutaneous tumours. J Pathol 154: 247-253 1988.

10) Matsumura, K., Sasaki, K., et al.: The nucleolar organizer regions associated protein (Ag-NORs) in salivary gland tumors. Int $\mathrm{J}$ Oral Maxillofac Surg 18: 76-78 1989.

11) Rosa, J., Mehta, A., et al.: Nucleolar organizer regions in gastric carcinoma and its precursor stages. Histopathology 16: 265-269 1990.

12) Ploton, D., Menager, M., et al.: Improvement in the staining and in the visualization of the argyrophilic proteins of the nucleolar organizer regions at the optical level. Histochem J 18: 5-14 1986.

13) Lischwe, M.A., Smetana, K., et al.: Proteins $\mathrm{C} 23$ and $\mathrm{B} 23$ are the major nucleolar silver staining proteins. Life Sci 25: 701-708 1979.

14) Hernandez-Verdun, D.: The nucleolar organizer regions (collective review). Biol Cell 49: 191-202 1983.

15) Hall, P.A., Crocker, J., et al.: A comparison of nucleolar organizer region staining and $\mathrm{Ki}-67$ immuno staining in non-Hodgkin's lymphoma. Histopathology 12: 373-381 1988.

16) Tanaka, T., Takeuchi, T., et al.: Nucleolar organizer regions in hepatocarcinogenesis induced by $\mathrm{N}$-2-fluorenylacetamide in rats: Comparison with immunohistochemistry using a monoclonal antibody against bromodeoxyuridine. Jpn J Cancer Res 80: 1047-1051 1989.

17) Crocker, J., Macartney, J.C., et al.: Correlation between DNA flow cytometric and nucleolar organizer region data in non-Hodgkin's lymphoma. J Pathol 154: 151-156 1988.

18）坂本寛文，田中卓二，他：乳腺細胞診に扣ける NORの画像解析. J Jpn Clin Cytol 29: 8358381990.

19）竹内敏視：膀胱腫瘍に扣忛る核小体形成体の研 究. 日泌尿会誌 81：1711-1719 1990 .

20) 坂本寛文, 山田正子,他: Ag-NORs (Nucleolar organizer regions) 染色の細胞診の応用。臨床 検査 33: 1800-1802 1989 .

21）天笠光雄, 戸塚盛雄, 他 : 口腔白板症の臨床型, 治療法と予後に関する研究一特に白板症の悪性 化について一。 日口外誌 24：243-252 1978.

22) 小浜源郁：口腔癌の化学療法効果に関する臨床, 病理, 細胞性免疫学的研究一特に臨床病理学的 悪性度とブレオマイシン効果拈よび予後につい て一。 口科誌 33: 672-698 1984.

23) Derenzini, M., Pession, A., et al.: Relationship between interphasic nucleolar organizer regions and growth rate in two neuroblastoma cell lines. Am J Pathol 134: 925-932 1989. 